\title{
Organizing Quality and Healthy Election Amid the Coronavirus Disease 2019 Pandemic: Election Health Protocol Policies and Neutrality of State Civil Servants
}

\author{
Sarjiyati Sarjiyati ${ }^{1 *}$, Anik Tri Haryani ${ }^{1}$, Bambang Heru Sutrisno ${ }^{2}$ \\ ${ }^{1}$ Fakultas Hukum, Universitas Merdeka Madiun, Madiun, Indonesia; ${ }^{2}$ FISIP, Universitas Merdeka Madiun, Madiun, Indonesia
}

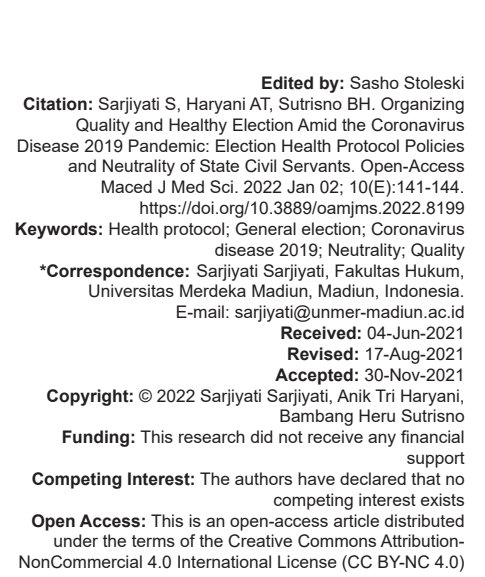

Introduction

The general election is the legitimatization source of a democratic government. Without it, the government does not have legitimacy among the public, causing chaos. Without a pandemic, there is no urgency to postpone a general election [1]. The Indonesian Head of the Region Election was scheduled to be organized on September 23, 2020. However, the coronavirus disease 2019 (COVID-19) pandemic resulted in the postponement of this event. This decision was made after a political consolidation between the executive and legislative officials and the General Election Commission.

The Government Regulation in lieu of Law No. 2 of 2020 accommodates the postponement of the 2020 general election due to the spread of the COVID-19 to December 9, 2020. The decision to still organize the 2020 general election caused polemics. Those who agree state that it is to maintain democracy and regional government continuity, considering that it is impossible to obtain legitimate leaders without a general election. Those who disagree believe that the government and the general election committee are not serious in handling the pandemic by still organizing the election. However, how prepared is the Indonesian government in preparing risk mitigations on the potential for new disease clusters due to the general election? [2]. The public's fear and concern for the pandemic may cause this great democratic event to fail to attract a maximum number of election participants and voters.

According to the Deep Knowledge Group Report from Forbes, April 13, 2020, Indonesia is a country that is categorized as having high risk in handling the COVID-19 pandemic [3]. This situation is worsened by the health service system and the healthcare security system is still lower than the universal health standard. The pandemic mitigation issues indicate a policy crisis [4].

In facing this simultaneous Head of the Region Election of 270 regions, consisting of nine provinces, 224 regencies, and 37 cities during the COVID-19 pandemic, the government issued Law No. 6 of 2020. Substantially, this law is the legal protection for the organization of the simultaneous Head of the Region Election while preventing the spread of the COVID-19 [5]. 
Apart from the pandemic, the neutrality of the state civil apparatus is a popular issue. This is due to the many cases of violations of the neutrality principle carried out by these apparatus during elections. The violations often happen before, during, and after 2015, 2017, and 2018 Head of Region Elections. The issue of the COVID-19 pandemic and the neutrality of the state civil apparatus are the two greatest issues in organizing the general elections in Indonesia [6]. Based on the problems above, this paper aims to analyze how to create a quality general election with the neutrality of the state civil apparatus.

\section{Methods}

This is juridical normative research that departs from primary data, namely, data that are directly obtained from library or others source including the source from society through field study that is carried out using observation, interview, or by spreading questionnaires [7].

This research uses primary and secondary data. The former is the data obtained directly from library because the juridical normative research was a library research and the secondary data extracted from the field. It is obtained from the social facts concerning how the law works in society, direct observation, and questionnaires [8]. The latter consists of constitutional regulations concerning the research object.

To determine informants, the researcher uses purposive sampling as a technique of data collection. It is a non-random sampling technique where the researcher obtains samples by determining special characteristics that are according to the research objective. It is carried out to answer the research problems [9]. This research uses qualitative analysis with inductive to deductive mindset. It is based on the components of data reduction, data presentation, and concluding [10].

\section{Results}

The Indonesian government observed the organization of other countries' general elections amid the pandemic, where 55 countries postponed the national or local general elections and national referendums. Then, 21 countries did not postpone it. Among them, nine have organized it amid the COVID-19 pandemic. South Korea is one of the countries that succeeded in organizing the general election on April 15, 2020 [11]. The success of several countries in organizing elections motivated the Indonesian government to also organize elections [12].
The government issued a health policy containing health protocols, namely, the Republic of Indonesia's General Election Commission Decree No. 13 of 2020 on the Second Amendment of the General Election Commission Decree No. 6 of 2020 on the Implementation of the Simultaneous Follow-Through Governor and Vice Governor, Regent and Vice Regent, and/or Mayor and Vice Mayor Election Amid the COVID-19 Non-Natural Disaster (hereinafter named GECD No. 13 of 2020). It states that COVID-19 has spread extensively all over the country. It also contains the evaluation of the stipulations of the General Election Commission Decree No. 6 of 2020, where the government determined that the campaign requirements must be changed according to the pandemic [13].

\section{Discussion}

Some risks must be cooperatively considered in organizing Head of the Region Elections amid the pandemic. Such an event may cause mass gatherings to occur, increasing the risk of virus infection. For example, on the $1^{\text {st }}$ day of the candidate pair registration on September 4, 2021, many candidate pairs from various regions caused gatherings by having convoys that lack the implementation of the COVID-19 health protocols. Some prospecting candidates were even infected by the virus. People fear that the organization of the Head of the Region Election will steeply increase the number of COVID-19 cases, leading to a crisis.

Another risk in organizing the Head of the Region Election is the risk of fraud. For example, there have been many cases of money politics in the past. The risk for this to happen increases during the pandemic as the weakening economy makes people have difficulties in fulfilling their needs. Thus, some people may choose candidates because they are bribed with some amount of money without considering their quality. Apart from that, there is the potential for violations in three stages of the simultaneous 2020 Head of the Region Election, namely, during the voting period, the vote count, and the recapitulation stage. In the recapitulation stage, there is a risk for the polling ballots to be opened outside of the official regulations. The collection of polls during the pandemic is carried out using new technologies. It is feared that these technologies may be misused.

To prevent the spread of the disease during the Head of the Region Election, there must be some policies to prevent the occurrence of new infection clusters. It is hoped that the Head of the Region Election Committees, the Head of the Regions, the Candidate Head of the Regions, Head of the Region Election Supervisors, and also state security apparatus may have active roles in creating a conducive situation in 
organizing this simultaneous 2020 Head of the Region Election on December 9, 2020.

One of the efforts to organize the simultaneous 2020 Head of the Region Election is by implementing Article 11 of the General Election Commission Decree No. 6 of 2020 on the Implementation of the Simultaneous Follow-Through Governor and Vice Governor, Regent and Vice Regent, and/or Mayor and Vice Mayor Election Amid the COVID-19 Non-Natural Disaster. Clause (1) of this decree states that all Head of the Region Election organizers, candidate pairs, campaign teams, candidate pair contact persons, and also all parties involved in the Simultaneous Follow-Through Election must implement the health protocols to prevent and control the spread of the COVID-19 as stipulated in Articles 5-9. It states that the minimum is by wearing masks that cover the nose, mouth, and up to the chin. Clause (2) of this decree states that parties who violate the obligation as stated in clause (1) will be warned by the Provincial General Election Commission, City/Regency General Election Commission, Staffing Officer, or Polling Station Committee to comply with the health protocols to prevent and control the spread of the COVID-19. Clause (3) of this decree states that if the person stated above have been warned as stated in clause (2) and still refrain from implementing the health protocols to prevent and control the spread of the COVID-19, the Provincial General Election Commission, City/Regency General Election Commission, Staffing Officer or Polling Station Committee coordinates with the Provincial Election Supervisory Agency, the City/Regency Election Supervisory Agency, or the District Election Supervisory Committee.

Health protocols must still be implemented in various activities, including at elections. Concerning the 2020 Head of the Region Election, the health protocols must be complied with, as stated in GECD No. 6 of 2020 as amended with the GECD No. 13 of 2020. Concretely, the government chooses to continue the stages of the Head of the Region Election but with strict limits [14]. People must comply with the health protocols in every stage of the 2020 Head of the Region Election, as there are consequences in violating them. There must be detailed information on how to comply with these protocols and what to do when there are health protocol violations during all stages of the 2020 Head of the Region Election. If not, the health protocol violations may facilitate the emergence of new COVID-19 infections. Mediaindonesia.com reports that 72 Head of the Region candidates were warned by the Ministry of Internal Affairs concerning health protocols in the 2020 Head of the Region Election. Then, 128.000 voters were warned as they violated the health protocols [15].

The protocols in the GECD No. 13 of 2020 discussed the limitations in the stages of the simultaneous 2020 Head of the Region Election. It includes the discussion in the campaign stage, where this decree limited the campaign process that was usually carried out by gathering many people, organizing fun walks, etc. This regulation prohibited these activities due to the ongoing pandemic, to prevent the increase of COVID-19 infections.

GECD No. 13 of 2020 Article 58 clause (1) stipulates that political parties or fusion of political parties, candidate pairs, campaign teams, and/or other parties must prioritize campaign methods with limited meetings and face-to-face meetings and dialogues through social media and online media. The aforementioned campaign methods may be carried out with the following requirements: (1) It is carried out indoors or in a building, (2) the participants are limited to 50 people and the social distancing of a minimum of $1 \mathrm{~m}$ must be maintained between campaign participants, and it may be carried out through social media and online media, (3) participants must wear self-protecting equipment; the minimum is a mask that covers the nose, mouth, and up to the chin, and (4) there must be a provision of adequate sanitation facilities. The minimum is a hand washing station with running water and soap and/or alcohol-based antiseptic liquid (hand sanitizer) [16].

Even with the stipulation of limitations, the Head of the Region Election Candidates failed to implement the health protocols maximally. The Election Supervisory Agency noted that there were 2.126 health protocol violations (where the participants exceeded 50 people, no social distancing, people lack wearing masks, and the absence of hand washing stations) and more than 1.126 neutrality violations during the 2 past months of the 2020 Head of the Region Election campaign. An Election Supervisory Agency member, Fritz Edward Siregar, stated that thousands of violations happened as candidate pairs preferred face-to-face campaigns instead of online-/internet-based ones. Therefore, many health protocol violations were found.

Due to the mass violation of health protocols, more than 72 candidates and 128.000 voters were given a warning. Apart from that, more than 60 election candidates were infected with the COVID-19 [17] and there was a significant increase of COVID-19 infections after the election, as reported by BBC [18]. In the case of neutrality violation of state civil servants, there were 484 cases where state civil servants supported a candidate pair in social media, 150 cases of state civil servants participating in political party socializations. Then, there were 103 cases where state civil servants approached political parties, 110 cases of state civil servants supporting a candidate pair, and 70 Head of Villages supporting a candidate pair.

The government's lack of strictness in acting on health protocol violations produces a significant increase of COVID-19 cases, filling hospitals after the elections [19]. This encourages the government to take a stricter policy in handling the pandemic, namely, by stipulating a simultaneous large-scale social restriction consisting of four levels for a month. It is a shame that the violation of health protocols during the Head of the Region Elections only ended in giving warnings. 
The candidates who mobilized masses, the voters who fail to comply with the health protocols, mass campaigns that cause health protocol violations and gatherings, as well as the success teams that are careless in organizing open campaigns, are all free from sanctions and were only given warnings. This becomes a bad precedent for the future. It is feared that the health protocol violations will be more massive as there is no application of strict sanctions [20].

In the case of neutrality, there is a stricter form of response. The 362 state civil servants who violated the neutrality principle during the 2020 simultaneous Head of the Region Elections obtained sanctions on November 5, 2020. These sanctions were given by the Staffing Officer according to the Joint Decision of Head of the State Civil Service, the Minister of State Apparatus Empowerment and Bureaucratic Reform, the Minister of Internal Affairs, the Head of the State Civil Servant Commission, and the Head of the Election Supervisory Agency. Then, what is disappointing is that most of the neutrality principle violators have high positions and only a small percentage $(12.9 \%)$ are executors [21]. The most of the violations $(25.7 \%)$ were carried out by people with functional positions, $22.8 \%$ were from high leadership positions, $14.6 \%$ are administrators, $12.9 \%$ are executors, and $11.5 \%$ are heads of villages/districts. Ironically, state civil servants without high positions are actually more neutral [22].

\section{Conclusion}

There are two things that cause public concerns in the organization of the region elections during the COVID-19 pandemic. The first is the increase of COVID-19 infection cases and the second is the neutrality of state civil servants. This research found the region elections did cause more infections as many health protocols were violated by General Commission Election, the candidate, the team of candidate, and the voters, and basically, the sanction was not implemented except the warning. In terms of neutrality of state public servants, there were thousands of violations against the neutrality principles and 362 apparatuses were given sanctions. The most of the violators are high-positioned officials and leaders, while only a small percentage consisted of executors.

\section{References}

1. Jurdi F. Legal Introduction to General Election. Surabaya: Kencana; 2018. p. 203.
2. Umayasari $U$, Kurniawan RC. Dynamics of the head of the region election amid the pandemic in fulfilling the constitutional mandate. Wacana Publik. 2020;14(2):59-69.

3. Rudolph CW, Allan B, Clark M, Hertel G, Hirschi A, Kunze F, et al. Pandemics: Implications for research and practice in industrial and organizational psychology. Industrial and Organizational Psychology. 2021 Jun;14(1-2):1-35

4. Lubis D. Simultaneous 2020 head of the region election amid the pandemic: Will it produce effective culture-based leadership? Kajian Lemhannas. 2020;42.

5. Hasanuddin, Marta A, Asrida W. Assessing the quality of head of the region election in pandemic era (study in Indragiri Hulu regency, Riau). Nahkoda. 2021;20(1):59-67.

6. Analysis and Development Center of KASN. Neutrality Supervision of State Civil Apparatus. Jakarta: KASN; 2018.

7. Efendi J, Ibrahim J. Normative and Empirical Legal Research Methods. Depok: Prenadamedia Group; 2018. p. 149.

8. Nugroho SS, Haryani AT, Farkhani. Legal Research Method. Surakarta: Oase Pustaka; 2020. p. 60.

9. Sugiyono. Qualitative Research Method. Bandung: Alfabeta 2017. p. 56.

10. Moloeng LJ. Qualitative Research Method. Bandung: Remaja Rosdakarya; 1995. p. 103.

11. Ristyawati A. Effectivity of the 2020 simultaneous head of the region election amid the emergency situation of the covid-19 pandemic in Indonesia. Crepido. 2020;2(2):85-96.

12. Nugroho SS, Sarjiyati S, Haryani AT, Purwati $Y$, Budiono A Kuswanto $\mathrm{H}$. The ethical philosophic dimension of responsibility in mitigating the COVID-19 disaster in Indonesia. Open Access Maced J Med Sci. 2021;9(E):1-5.

13. Wijaya R. Implementation of health protocols as a violation of the 2020 head of the region election. Supremasi. 2021;11(2):81-91.

14. Mas'udi W, Winanti PS. Introductory Analysis of Covid-19 Management in Indonesia. Yogyakarta: UGM Press; 2020.

15. Izziyana WV. Harun H. Absori A. Wardiono K. Nugroho HSW. Budiono A. Health insurance for Indonesian migrant workers. Med Legal Update. 2019;19(1):188-92.

16. Nuryanti S, Mouliza K, Sorik S. Policy Brief Polemics of Election Organisation Amid the Covid-19 Pandemic. Jakarta: LIPI; 2020.

17. Maja MA. General Election Commission: 60 Head of the Region Election Candidates are Infected with Covid-19. Available from: https://nasional.kompas.com/read/2020/09/10/15313681/kpu60-calon-kepala-daerah-terpapar-covid-19 [Last accessed on 2021 Jul 17].

18. BBC. The Head of the Region Election: A Coronavirus Cluster Emerged after the Head of the Region Election; Experts State it is Due to a Weak Contact Search. Available from: https://www. bbc.com/indonesia/indonesia-55321183 [Last accessed on 2021 Jul 19].

19. Wardiono K, Dimyati K, Nugroho SS, Nugroho HS, Acob JR. Philosophy, law, and ethics of handling COVID-19 pandemic in Indonesia. Open Access Maced J Med Sci. 2021;9(E):1104-8.

20. Ambardi K. Implementation of the 2020 Simultaneous Head of the Region Election: Application of the Fairness Principle Amid the Pandemic. Yogyakarta: UGM Press; 2020.

21. Sardini NH. Challenges and Opportunities of the 2020 Head of the Region Election Amid the Pandemic. Challenges and Opportunities of the 2020 Head of the Region Election Amid the Pandemic National Seminar; 2020.

22. Hergianasari P. Electoral distancing: Alternative in implementing the Challenges and opportunities of the 2020 head of the region election amid the pandemic in Indonesia. Magistrorum Scholarium. 2020;1(1):31-43. 